\title{
Introduction to Secretary Major and Construction Planning
}

\author{
Lin Tian \\ Baotou Light Industry Vocational Technical College, Baotou, 014035, China
}

Keywords: Secretary major; Construction planning; Construction objectives; Existing problems

\begin{abstract}
The secretary major requires that the students must have the attainment of Chinese language and literature, and also have the operation ability to engage in the secretary work, thus we shall carry out specific education research on secretary major. This paper starts from the concept of secretary major to analyze the education status of secretary major, propose solution measures for existing problems, and establish the construction objectives.
\end{abstract}

\section{Introduction to secretary major}

\section{Overview of secretary major}

The professional courses established in secretary major mainly include: philology, public relations, secretary writing, secretary work, outline of traditional Chinese culture, communicative language study, communicative etiquette, speedy recording, and news gathering and writing, etc. The secretary major is established in market demand; in consideration of the talent demand of basic-level administrative units, this major focuses on cultivating modern talents who can master modern office equipment, have certain literary quality and wide cultural horizon and innovative ability, and are capable of secretary work, cooperation and communication with others.

\section{Positioning of secretary major}

The main reason why we need to enhance cultivating the talents of secretary major includes three aspects as below:

1). With the rapid development of national economy, many newly-added industries need the professional talents who have the knowledge and skills of secretary major;

2). With the continuous improvement of living standard in contemporary era, people's demand of spiritual culture continuously increases, and the task of improving national people's cultural quality and inheriting and promoting Chinese excellent cultural tradition is in urgent need of large quantity of professional talents;

3). With the deepening of the reform and opening-up, China's international position is continuously improved; to spread Chinese culture to the world is our historic mission, which shall be supported by more professional talents.

\section{Construction planning of secretary major}

\section{Guiding thought for major construction}

In order to enhance the major construction, we shall insist on correct construction thoughts, which mainly include: learning "Deng Xiaoping Theory" and "Scientific Outlook on Development", insisting on socialist modernization school-running principle, following China's law of education, implementing national education policy, improving students' quality, and promoting the integrated development of talents. Firstly, we shall pay attention to the functional demand of secretary work, enhance cultivating the occupational skills and post quality of secretary major, and cultivate the professional talents which can adapt to works of enterprise and public institutions, and party and government offices. Secondly, we shall carefully implement educational policies of the Party and state, follow the law of education, realize the view of modern education, adapt to modern remote education development trend, pay attention to lifelong education, adult education, open education, and remote education, and also determine the unique education direction according to different education types. Thirdly, we shall insist on cultivating the talents with practice and innovative ability, 
and enhance the teaching work to improve overall teaching quality and cultivate the students' innovative and practice awareness. Finally, we shall pay attention to carrying out systematic, comprehensive, and continuous reform, make use of specific major construction to promote the basic construction of various kinds of teaching, and further deepen the reform to improve the talents' comprehensive quality.

\section{Cultivation objectives of secretary major}

The secretary major focuses on cultivating the practical professional talents who can adapt to the demand of socialist modernization, have all-round development of morality, intelligence physique and aesthetics, and are capable of secretary work. This major aims at cultivating graduates' following 6 abilities:

1). To master Marxism and fundamentals of socialism with Chinese characteristics, and know China's national conditions;

2). To master the basic theoretical knowledge of secretary major, and know the relevant knowledge of subjects such as news, history, and arts;

3). To cultivate students' literary accomplishments, and improve their ability of literature appreciation;

4). To know China's policies and rules related to language and character art, and follow China's culture rules;

5). To cultivate students' ability of reading classical literature and mastering the methods of data retrieval and document query to make students get actual working ability;

6), To cultivate students' actual skills, and enhance cultivating their professional ethics and occupational skills.

\section{Major construction principles}

The secretary major shall cultivate the talents who have certain literary and cultural literacy and can adapt to the works of party and government offices and enterprises, and the major construction shall follow the 4 aspects of principles: firstly, we shall insist on human-oriented principle to fully consider students' future development demand, pay attention to students' work and cultivating students' ability, and improve students' professional skills; secondly, we shall take the market demand and social demand as teaching standard to cultivate students' professional abilities, realize students' full employment, and continuously improve teaching scheme according to the market demand; thirdly, we shall often carry out education reform, insist on the concept of "paying attention to cultivation of professional skills", and perfect our teaching system; fourthly, we shall advocate students to exert their subjective initiative in learning, and the teachers shall enhance their interaction with students to promote students' autonomous learning.

\section{Construction objectives of secretary major}

\section{Course objective}

1). To perfect the construction of basic compulsory courses, educate students and carry out academic education for students through compulsory courses so as to realize the objective of providing professional language talents for social construction;

2). To establish elective courses through which it is able to further perfect education system, improve students' comprehensive quality, and advocate students to establish correct view of learning, carry out lifelong learning, meet continuously increased cultural demand, insist on talent construction objective, improve national quality, and inherit Chinese traditional culture;

3). The curriculum design is not only established in contemporary era, but also considers the future development demand. Through research on market demand, it is able to continuously improve current curriculum arrangement, realize resource sharing, and improve the overall teaching quality.

\section{Faculty objective}

It is required to continuously carry out educational reform, establish high-level teaching staff, including the construction of consultant team and professional teaching team, pay attention to the teachers' professional ability and interactive ability, set up professional center teaching and research 
team, enhance the faculty construction, pay attention to teachers' qualifications, and suitably carry out teacher training to improve teachers' teaching level.

\section{Teaching objective}

1). To advocate students to carry out active and independent study; guide students to participate in learning activities, read more books, and carry out positive thinking and independent study through daily education;

2). To construct new-type education means, make use of technological innovation to set up network learning platform which adapts to current science and technology, and set up interesting teaching courses to guide students' learning.

3). To establish rich learning atmosphere, cultivate students' learning interest. The teachers shall consider to adopt new-type teaching mode so as to promote students to carry out research and then gradually improve students' learning enthusiasm.

4). To teach students according to their aptitude. Each person has different ability; in order to better cultivate talents, the attention shall be paid to the difference in personal quality so as to improve the overall level of quality.

5). To enhance the training of occupational ability and train students' skills. It is able to adopt secretary qualification certificate and computer certificate as one of assessment standards.

\section{Student objective}

1). To cultivate students' practical ability. The attention shall be paid to theoretical courses, and the lack of actual operation ability is the inherent drawback of modern education. Therefore, the education of secretary major shall enhance cultivating the practical ability, encourage students to participate in practice learning and enter into enterprises to take internship so as to let them know the occupational ability and moral quality which a secretary shall have and then further improve students' competitiveness.

2). To cultivate students' ability of expression. Due to the fact that the secretary talents carry out "transmission" work in enterprises, they shall have good ability of expression and communication: in terms of oral expression, the students shall learn mandarin well, and the general requirement is class two level one, with clear articulation and fluent expression; in terms of written expression, the students shall master the writing method of transactional documents and office documents with clear logics and beautiful writing so as to ensure the correct transmission of information.

3). To cultivate students' business ability. The secretary major shall pay attention to cultivating students' business negotiation ability, and improve students' awareness of public relations so as to ensure that the students can carry out reception work in compliance with rules, conduct themselves nobly, and formulate scientific business negotiation documents.

4). To cultivate students' organization and management ability. The secretary work is to assist the leaders to carry out management, and timely handle corporate relevant problems, thus the students shall have the organization and management ability, know organizational form, skillfully apply management method, and then improve the corporate working benefits.

5). To cultivate students' actual office ability. It is required to cultivate students' ability of mastering modern office equipments, skillfully applying the computer to enter the content, draw forms, and write reports, being able to use common copying machine, electronic scanner, and fax machine to deliver documents, as well as the ability of speedy recording and actively coordinating with superior's work.

6). To cultivate students' writing ability. As a type of work related to information recording and transmission, the secretary shall ensure no mistake in the information transmission, thus the secretary personnel shall have standard writing.

\section{Problems existing in major construction}

As a kind of major linked to market demand, the secretary major has strong practicality; however, in terms of current development, there still exist many problems. Firstly, there are excessive Chinese courses in secretary major, and the mere application of the thinking mode of art will cause students' fixed thinking and lack of flexibility. Secondly, the setting part of secretary major and speedy recording major is repeated, and the subdivision is not made for these two majors, which causes 
unclear powers and responsibilities and repeated content. Thirdly, in the secretary major, partial courses are very difficult, which influences students' learning attitude, thus it is required to consider to actively guide students to carry out learning and tackle the difficulties. Fourthly, only few network courses are arranged in secretary major; on the network platform, there is little course data about this major, which causes great difficulty for students to carry out independent study after class, thus it is required to consider to add some course data for online learning.

\section{Development measures for major construction}

\section{To construct complete teaching system}

The traditional teaching mode can't fully motivate students' learning enthusiasm, thus it is required to carry out active innovation on teaching mode and establish a new teaching mode which pays equal attention to theoretical teaching, quality-oriented teaching, and practical teaching. The theoretical teaching requires to perfect teaching courses, and it is able to establish the basic courses such as Chinese traditional culture, literary appreciation, official writing, documents and archives management, and mandarin to improve students' literature quality, as well as set up professional courses such as practical knowledge of secretary, economics, communicative etiquette, and enterprises and administrations, and apply professional courses to cultivate students' professional knowledge so as to enhance their occupational skills. The quality-oriented teaching requires that the students shall have correct value orientation, love the party, love the state, and love the work; through Introduction of Marxism and Mao Zedong Thought, it is able to guide students to establish correct value. Besides, the students shall master the theoretical knowledge of their major to help them quickly adapt to work environment, thus the continuous guidance shall be made in the daily teaching. The practice teaching requires that the students shall have actual operational ability, own professional knowledge and apply it into practice. In the teaching process, we shall actively guide students to participate in practice so as to improve their practice ability.

\section{To improve teachers' teaching level}

To a great degree, the students' learning knowledge originates from teachers, thus the teachers' level will influence students' ability. Therefore, to enhance double-teaching construction can help to carry out teaching work. The double-teaching refers to the situation that two kinds of teachers form teaching team: one kind of teachers are teachers with strong theoretical knowledge and rich teaching experience, and another kind of teachers have practical experience of secretary work. The $1^{\text {st }}$ kind of teachers can teach students professional theoretical knowledge, and the $2^{\text {nd }}$ kind of teachers can teach students actual working ability and deliver current post information. The double-teaching mode can promote the improvement of students' integrated quality and let them become more competitive.

\section{To select professional textbooks}

The textbooks shall be selected according to students' ability to realize standard textbooks. Firstly, the standard textbooks shall account for $70 \%$ of overall textbooks; those textbooks are reviewed by the state and have strong theoretical property. Secondly, on the basis of students' ability and actual demand, the development is made for professional textbooks, and the independently complied textbooks are used to supplement teaching content so as to promote students' integrated development.

\section{To construct in-campus practice site}

The main reason why the students lack of practice ability is that they lack of practical training, and the lack of relevant training equipments in campus is the main reason which causes the lack of practice. Therefore, it is required to set language classroom for students' learning, and establish good archives process management laboratory. Due to strong practicality of archives management, it is hard for students to understand it under the condition of lack of practice; however, after establishment of laboratory, the students can learn the process management in laboratory and make use of intuitional teaching condition to learn this course. Besides, it is able to establish training assessment system to carry out frequent assessment on training learning so as to investigate the result of training teaching, and continuously innovate and reform the problems. 


\section{To construction off-campus connection practice base}

It is required to advocate students to carry out practice, enhance the connection between schools and enterprises, and establish practice base. Through participating in specific practice, it is able to cultivate students' actual operation ability, let them know the occupational ability of secretary work, and then carry out targeted practice. The secretary major shall enhance the connection with enterprises in the city, and seek for winning 3-5 excellent enterprises to carry out coordination work and establish a benign interactive practice platform so that the students can participate in enterprise practice and the enterprises can select excellent students. In this way, it is able to improve students' comprehensive ability and guarantee students’ employment.

\section{Conclusion}

In conclusion, the secretary major is closely linked with market demand, and the secretary work requires that the schools shall cultivate talents with integrated development. Therefore, on the basis of current situation of poor practicality, plentiful and difficult courses, the secretary major shall continuously deepen the reform, improve teachers' level, and create practice base to further improve students' practice ability; however, the education of secretary major shall be not in hurry, and the reform shall be made in a down-to-earth way.

\section{Acknowledgments}

Fund project: Baotou Municipal Science and Technology Bureau: Research on Traditional Cultural Education in Vocational Colleges; project No.: 2012S2005-3

\section{References}

[1] Wang Mengyu: Secretary Personnel Demand of Middle and Small-sized Enterprises, Jinan University, 2013(5): 18-23.

[2] Wu Qianqian: Research on Identification Status for Secretary Qualification in China, Jinan University, 2014 (6): 22-26.

[3] Mi Lijuan: Medium Attainment Course System about Promoting the Improvement of Modern Secretary Ability - take Chongqing University of Arts and Sciences as an example, Educational Research, 2014 (7): 55-56.

[4] Wang Haimei: Research on Countermeasures for Talent Cultivation of Secretary Major in Local Colleges, Shandong Normal University, 2010 (5): 33-38.

[5] Li Qinghua: Preliminary Exploration on Compilation Thinking of Oral Communication Course Textbooks for Secretary Major in Secondary Vocational Schools and Partial Experience, Capital Normal University, 2011 (5): 55-58.

[6] Yang Hao, Guo Kai: Discussion on Several Points of Improving Secretary's Work Ability - take the post demand of one enterprise as an example, Journal of Wanxi University, 2013 (7): 45-46. 